\title{
International Journal of Languages' Education and Teaching
} Volume 7, Issue 2, June 2019, p. 294-318

\begin{tabular}{cccc}
\hline Received & Reviewed & Published & Doi Number \\
\hline 17.04 .2019 & 28.05 .2019 & 30.06 .2019 & $10.18298 /$ ijlet.12383 \\
\hline \multicolumn{4}{r}{ Teachers' Perceptions of Assessment in EFL Classes } \\
at Turkish Science and Arts Centers ${ }^{1}$
\end{tabular}

Hüseyin ATEŞ ${ }^{2}$ \& Kağan BÜYÜKKARCI ${ }^{3}$

\begin{abstract}
The aim of this study is to investigate English language teachers' perceptions of assessment in English as a Foreign Language (EFL) classrooms in a Turkish Science and Arts Centers (BILSEM) context. There is no study on how English language teachers assess EFL learners at BILSEM, what they think about the assessment techniques in practice, and therefore this study will be original in its field and undertake a pioneering role for illuminating the further research focusing on assessing gifted learners in EFL classrooms at BILSEM. In this study, the data were obtained from 61 English language teachers from 61 BILSEM in Turkey. As a data collection method, a Teachers' Conceptions of Assessment Abridged Scale (TCoA-IIIA) was used. Also, to gather teachers' opinions, interviews were held with the English language teachers working at 5 different BILSEM. The study results indicated that the teachers used Student Written Work assessment practice mostly to assess their students' language performances and language achievement in their classes. Also, according to the teachers, assessment is a force to make them teach English in a way that is against their beliefs. Besides, they think that assessment does not measure students' higher order cognitive skills, such as analyzing and evaluating anyway.
\end{abstract}

Key Words: Assessment, science and arts centers, teachers' perceptions, EFL classes.

\section{Introduction}

Assessment is such a broad concept that it appears as an indispensable event that is in any age, any teaching environment, any institution, any training, briefly in any environment where learning is expected to occur (Gülbahar \& Büyüköztürk, 2008). Moreover, regarding the field of education, it is an on-going process, and its results will contribute to education process only when it is continuous. It is also a process which builds the teacher's understanding of what the students can and cannot do and also helps the students to see what they can and cannot do. In other words, assessment process and practices influence both teachers and students in many aspects.

\footnotetext{
${ }^{1}$ This paper was produced partly from author's MA thesis.

${ }^{2}$ Burdur Alpaslan Ali Can Science and Arts Center, huseyinates15@yahoo.com

${ }^{3}$ Dr., Süleyman Demirel University, kaganbuyukkarci@sdu.edu.tr
} 
Assessment is generally categorized into two groups: Traditional and alternative assessment. Traditional assessment is an assessment type focusing mainly on the product and including traditional tests, such as pencil and paper exams, quizzes, standardized tests, etc. Alternative assessment is an assessment type focusing on the process and including self-assessment, peer assessment, portfolio assessment, learner-centered assessment, projects, etc. In Turkey, teachers are more familiar with traditional assessment, and especially the teachers working at regular schools in Turkey mostly prefer traditional assessment to assess their students' language performances in their classes. On the other hand, according to Şahin and Karaman (2013), many teachers consider that alternative assessment is generally more time-consuming and labour intensive than traditional assessment. Furthermore, language teachers in Turkey are not adequately concerned with alternative assessment (Büyükkarcı, 2010). Also, as to alternative assessment techniques, teachers' knowledge about them is limited (Büyüktokatlı \& Bayraktar, 2014; Yayla, 2011). However, unlike the teachers teaching at regular schools, at BILSEM, teachers use mainly alternative assessment methods while teaching English to their students in EFL classrooms when compared to traditional assessment methods which these students are mostly exposed to during their English classes at their own regular school. Therefore, the extent of effectiveness and significance of alternative assessment used at BILSEM must be determined, and teachers must have knowledge of how to use these assessment type and tools properly in their classes.

In Turkey, education of gifted children is also a relatively new concern in comparison with other countries. In parallel with this situation, although assessment has a vital role in English language teaching process, there is no study on which assessment tools English language teachers at BILSEM prefer and use to assess their pupils and what their conceptions regarding assessment in BILSEM EFL classrooms are. Therefore, exactly at this time, it is prominent to find answers to the questions related to what conceptions English language teachers have concerning assessment. Thus, this study will shed light on the assessment conceptions and especially the appropriate assessment strategies used by English language teachers while teaching English to gifted pupils in Turkey by investigating and identifying various unidentified issues about assessment.

This study aims to investigate the conceptions of BILSEM English language teachers regarding assessment in EFL classrooms. Also, it is aimed to find out these teachers' assessment practices they used to assess their pupils in their classes. The research questions of the present study are as follows:

1. What are the BILSEM English language teachers' perceptions of assessment in terms of: School Accountability, Student Accountability, Improvement, and Irrelevance?

2. What is the relationship among the four components of TCOA-IIIA?

3. What types of assessment practices do the BILSEM English language teachers choose?

\section{Conceptual Framework and Related Studies}

Since the general scope of the study is investigating into how English language teachers assess gifted learners in EFL classrooms at BILSEM in Turkey, what kind of assessment techniques they use to assess their students, the conceptions and opinions of English language teachers regarding assessment that is used to judge the gifted learners are identified and analyzed in this study. Besides, the definitions, types and purposes of assessment and teachers' conceptions of assessment are explained in this section. 


\subsection{Definitions and Types of Assessment}

According to Lambert and Lines (2000), assessment is "a fact of life for teachers, part of what teachers do; an organic part of teaching and learning; and using assessment evidence is part of the planning process" (p. 2). Assessment is not a separate part of education, in other words, it is a significant part of education and has a significant role in education process. It is "a tool or method of obtaining information from tests or other sources about the achievement or abilities of individuals" (Glossary of Important Assessment and Measurement, n.d.). Assessment is an on-going process, and it is conducted to observe and improve student learning, as well as all the subjects taught in a school or educational environment and the teaching that occurs within it (Huba \& Freed, 2000).

According to Brown, H. D. (2004), assessment that is popular in present educational concept is sometimes misunderstood. It is usually understood as the tests that students take at the end of the semester or educational year through pencil and paper to determine how successful the teacher and the students are. However, it is not only about tests. There are many activities and ways of assessing the teacher him/herself and the students' growth from different aspects (Coombe, Folse, \& Hubley, 2007).

Assessments are generally categorized as summative or formative in today's schools. The most important distinction between formative and summative assessment concerns the purpose and the outcome, not the timing (Sadler, 1989). Summative assessment, also called assessment of learning, occurs when teachers use evidence of student learning to make judgments on student achievement against goals and standards at the conclusion of one particular period. Formative assessment, also called assessment for learning, occurs when teachers use inferences about student progress to inform their teaching, and in addition to this, formative assessment, also called assessment as learning, occurs when students reflect on and monitor their progress to inform their future learning goals (Assessment, n.d.). In other words, the notion of a formative test denotes the idea that the teacher will be able after evaluating the results of the test reconsider his/her teaching, syllabus design and even slow down the pace of studying to consolidate the material if it is necessary in future.

According to author (2010), formative assessment or dynamic assessment is about supporting students to enhance their performance in classroom. On the other hand, teachers use summative assessment to obtain information on how well students are doing, and they grade or mark or score students at the end of the summative assessment (Büyükkarc1, 2010). Summative assessment evaluates the success and understanding of the learner at the end of a topic, course or unit (Brown, 2004). In relation to this, Sadler (1989) stated that formative assessment differs from summative assessment in that the latter is more concerned with reporting the achievement of the learner towards the end of the course or unit, rather than monitoring what progress is being done throughout the course.

For different purposes, teachers need different types of assessment and administer them at different stages of the course to gather information about students. Teachers should choose the best option to assess their particular group of students in their particular teaching context. Assessments should be categorized by type, purpose, or place within the teaching/learning process or timing (Coombe et al., 2007). 


\subsection{Purposes of Assessment}

Assessment has various roles, and these roles serve for various purposes as described in this section. According to Wiggins (1998), the primary purpose of assessment is to educate and improve students' learning and performance. Also, it improves teachers' teaching as both respond to the information it provides.

Assessment can do more than simply diagnose and identify students' learning needs; it can be used to assist improvements across the education system in a cycle of continuous improvement. There are so many purposes of assessment; teachers must decide on classroom equilibrium, supply feedback and incentives to their students, realize students' problems and judge and grade academic learning process. Assessment consists of three major domains: The cognitive domain includes intellectual activities; the affective domain includes feelings, and the psychomotor domain involves physical activities and actions (Airasian \& Russell, 2012).

Purposes of assessment are also described as follows: The essential purpose of assessment is to place students in the right level of classroom instruction. The others are to diagnose student problems, in other words, to learn about students' strengths and weaknesses with diagnostic assessment, to learn about the language proficiency of the students, to evaluate academic performance, to learn about students' immediate needs (instructional decision-making), and some of the assessment activities are for accountability purposes, in other words, assessment not only affects students and their families but also teachers' school administration, and the community where they work (Coombe et al., 2007).

\subsection{Assessment Conceptions of Teachers}

According to Brown, G. T. L. (2004), teachers' conceptions are not monotonous and simple, but versatile and interconnected. Teachers' assessment styles, which they use to assess students' level of knowledge, can show us that assessment types are not stated with their goals and objectives. Moreover, teachers' perceptions of what learning is and the variety of assessment forms can be affected by concerns about keeping students' attention constant, collaboration and teachers' control of classroom (Kahn, 2000).

Brown (2003) states that "the structure of the interrelationships of these conceptions among a survey population of $525 \mathrm{New}$ Zealand primary school teachers was analyzed using a structural equation measurement model with good fit to the data, and four main instructional conceptions were found" (p. 2). In other words, he points out that there is an ongoing discussion about the use of assessments in schools. Some teachers argue that assessments are useful, because they improve teacher quality and student learning. However, if attachments are a final goal (the certification), and are not seen as a part of the learning process, the use of assessments might be irrelevant. Brown, G. T. L. (2004) adds that teachers' conceptions of assessment "can be understood in terms of their agreement or disagreement with four purposes to which assessment may be put, specifically, (a) improvement of teaching and learning, (b) school accountability, (c) student accountability, or (d) treating assessment as irrelevant" (p. 301). According to most teachers, assessment is for improvement of teaching and learning and school accountability.

Davis and Neitzel (2011) say that assessment depends on four characteristics: 1- How effective and efficient feedback teachers give. 2- How often students use their cognitive and metacognitive factors in 
learning process. 3- How they can work in group or independently, and 4- How teachers realize the function of their daily assessment. Last of all, Brown, G. T. L. (2004) stated that "teachers' conceptions of assessment were general and constant and clearly related to what are commonly seen as classroom assessment tasks" (p. 312). The analyses in his study indicated "the relative stability and generalizability of teachers' assessment conceptions regardless of school or teacher demographic characteristics" (p. 312).

\section{Methodology}

This chapter will give information on the pilot study, participants, data collection process, data collection tools and data analysis.

\subsection{Pilot Study}

For piloting the instrument of data collection for this study, the questionnaires (TCoA-IIIA) were distributed to the 32 English language teachers teaching at different state schools in Burdur. According to the results of the reliability analyses, the Cronbach's Alpha for the 'assessment practices section' in TCoA was obtained as .97, and the Cronbach's Alpha for the 'statements section' indicating teachers' perceptions of assessment in TCoA was obtained as .79.

\subsection{Participants}

In the main research, the data were obtained from 61 English language teachers (45 female and 16 male) teaching at BILSEM. The teachers participating in this study revealed the following years of experience: 2 teachers had less than 2 years of teaching experience, 8 teachers had between 2 and 5 years of teaching experience, 14 teachers had between 6 and 10 years of teaching experience, and 37 teachers had more than 10 years of teaching experience. Furthermore, it was observed that the highest degree of the participants ranged from the following: doctoral level $3(4.9 \%)$, postgraduate certificate level $4(6.6 \%)$, postgraduate diploma level $5(8.2 \%)$, master level $20(32.8 \%)$, and bachelor level 29 $(47.5 \%)$.

\subsection{Data Collection Tools}

Chamot, Barnhardt, El-Dinary and Robbins (1999) suggested using more than one way to collect data and collecting information on an ongoing basis. Therefore, in this study, mixed method approach was preferred to collect data. The researchers adopted both quantitative and qualitative research methods to conduct their study. The data collected from the questionnaires was subjected to SPSS version 21. In order to get results for the independent variables, Frequency analyses were done. To find out the results in order to answer the research questions, Independent Samples T-test, One-way ANOVA and Pearson Correlation analysis were used.

\subsubsection{Teachers' Conceptions of Assessment Abridged Scale (TCoA-IIIA)}

In this study, to identify English teachers' conceptions and opinions about the assessment used in EFL classrooms at BILSEM, as a data collection method, a TCOA-IIIA originally developed by Brown (20012003,2008 ) and including three parts was used. 
According to Brown and Michaelides (2011), the TCoA-IIIA (Brown, 2006, 2008) is a self-report multidimensional survey instrument designed to elicit teachers' level of agreement with four competing purposes of assessment (i.e., improvement, school accountability, student accountability, and irrelevance). In addition to interpreting mean scores for each of these four scales, the inventory allows for more complex interpretations by examination of the inter correlations among the four scales and the paths to the contributing 1st-order factors which make up the irrelevance and improvement scales.

The TCoA-IIIA by Brown (2001-2003, 2008) was as follows: In the first part, there was a list of 12 assessment tools, and the teachers were asked to indicate the assessment tools that they had in mind when they thought about assessment. In the second part, there were 27 statements to indicate teachers' perceptions of assessment using a six-point Likert-type rating scale, which were Strongly Disagree (1), Mostly Disagree (2), Slightly Agree (3), Moderately Agree (4), Mostly Agree (5), and Strongly Agree (6). In the third part of it, there were questions prepared by Brown in order to get the demographic information of the participants. These questions also elicit the necessary information for the independent variables. After conducting the survey on 61 participants the reliability analyses were administered again. The results showed that both parts of the questionnaire had high level of reliability with Cronbach's Alpha of .95 for the 'assessment practices part' and Cronbach's Alpha of .87 for the 'statements part' indicating teachers' perceptions of assessment. The adapted questionnaire was also checked by a lecturer from Department of Foreign Language Education and several English language teachers working at different state schools. The original form of this questionnaire is in English. The data collected from the questionnaires was subjected to SPSS version 21.

\subsubsection{Interview}

The interview is deemed as an efficient means to have deeper insights into someone's experiences, opinions (Lambert, 2012). For this purpose, the researchers performed semi-structured interviews including 8 questions with 5 teachers to better understand their views. The qualitative data collected from the interviews was subjected to a peer review. In peer review, the open review technique was used to examine the qualitative data. Thus, the researchers added new dimensions and qualifications to their ideas and comments related to the data that they collected and made clearer comments about the data in this way.

\section{Results}

This section presents the BILSEM English language teachers' perceptions of assessment in terms of: Improvement, School Accountability, Student Accountability, and Irrelevance.

\subsection{Results of the Quantitative Data}

\subsubsection{Teachers' perceptions of assessment}

The first concept that TCOA focuses is the improvement conception of the teachers. According to the study of Brown (2007), the improvement conception had four contributing factors (i.e., assessment describes student learning, assessment is valid, assessment improves student learning, and assessment improves teaching). In the table below, the teachers' perceptions related to improvement are given. 
Table 1. Items related to improvement

\begin{tabular}{|c|c|c|c|c|c|c|c|c|c|c|c|c|}
\hline \multirow{3}{*}{$\begin{array}{l}\text { Items } \\
\text { 3.Assessment is a }\end{array}$} & \multicolumn{6}{|c|}{ Frequencies } & \multicolumn{6}{|c|}{ Percentages (\%) } \\
\hline & SD & MD & Sl.Ag. & Mod. & MA & SA & SD & MD & Sl.Ag. & Mod.Ag & . MA & SA \\
\hline & 1 & 4 & 7 & 13 & 20 & 16 & 1.6 & 6.6 & 11.5 & 21.3 & 32.8 & 26.2 \\
\hline \multicolumn{13}{|l|}{ way to determine } \\
\hline \multicolumn{13}{|c|}{ how much students } \\
\hline \multicolumn{13}{|l|}{ have learned from } \\
\hline \multicolumn{13}{|l|}{ teaching } \\
\hline 4.Assessment & 0 & 1 & 6 & 12 & 23 & 19 & 0 & 1.6 & 9.8 & 19.7 & 37.7 & 31.1 \\
\hline \multicolumn{13}{|l|}{ provides feedback } \\
\hline \multicolumn{13}{|l|}{ to students about } \\
\hline \multicolumn{13}{|l|}{ their performance } \\
\hline 5.Assessment is & 0 & 2 & 6 & 15 & 22 & 16 & 0 & 3.3 & 9.8 & 24.6 & 36.1 & 26.2 \\
\hline \multicolumn{13}{|l|}{ integrated with } \\
\hline \multicolumn{13}{|l|}{ teaching practice } \\
\hline 6.Assessment & 2 & 8 & 16 & 23 & 11 & 1 & 3.3 & 13.1 & 26.2 & 37.7 & 18.0 & 1.6 \\
\hline \multicolumn{13}{|l|}{ results are } \\
\hline \multicolumn{13}{|l|}{ trustworthy } \\
\hline 12.Assessment & 1 & 2 & 13 & 23 & 18 & 4 & 1.6 & 3.3 & 21.3 & 37.7 & 29.5 & 6.6 \\
\hline \multicolumn{13}{|l|}{ establishes what } \\
\hline \multicolumn{13}{|l|}{ students have } \\
\hline \multicolumn{13}{|l|}{ learned } \\
\hline 13.Assessment & 0 & 2 & 7 & 20 & 16 & 16 & 0 & 3.3 & 11.5 & 32.8 & 26.2 & 26.2 \\
\hline \multicolumn{13}{|l|}{ feeds back to } \\
\hline \multicolumn{13}{|l|}{ students their } \\
\hline \multicolumn{13}{|l|}{ learning needs } \\
\hline 14.Assessment & 0 & 2 & 12 & 22 & 19 & 6 & 0 & 3.3 & 19.7 & 36.1 & 31.1 & 9.8 \\
\hline
\end{tabular}


information

modifies ongoing

teaching of

students

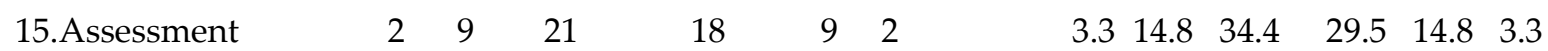

results are

consistent

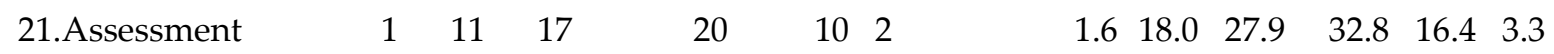

measures students'

higher order

thinking skills

22.Assessment

$\begin{array}{lll}1 & 1 & 13\end{array}$

$21 \quad 1510$

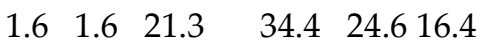

helps students

improve their

learning

23. Assessment

$\begin{array}{lll}3 & 7 & 15\end{array}$

20

115

$\begin{array}{llllll}4.9 & 11.5 & 24.6 & 32.8 & 18.0 & 8.2\end{array}$

allows different

students to get

different

Instruction

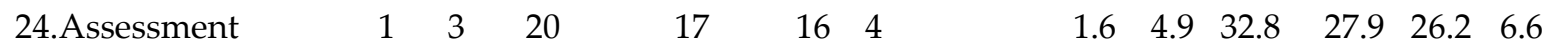

results can be

depended on

$\begin{array}{llr}\mathrm{SD}=\text { Strongly Disagree } & \mathrm{MD}=\text { Mostly Disagree } & \text { Sl.Ag.= Slightly Agree } \\ \text { Mod.Ag.= Moderately Agree } & \mathrm{MA}=\text { Mostly Agree } & \text { SA= Strongly Agree }\end{array}$

As Table 1 presents, items 3, 4, 5, 6, 12, 13, 14, 15, 21, 22, 23, and 24 are related to Improvement Conception. Table 1 shows that $32.8 \%$ of the teachers mostly agreed, and $26.2 \%$ of the teachers strongly agreed with Item 3. It means that $59.0 \%$ of the teachers use assessment as one of the ways to determine how much students have learned from teaching. Likewise, $37.7 \%$ of the teachers mostly 
agreed, and $31.1 \%$ of the teachers strongly agreed with Item 4 , and $26.2 \%$ of the teachers mostly agreed, and $26.2 \%$ of the teachers strongly agreed with Item 13 . These two items are related to feedback to students, and it can be said that for the majority of the participants, assessment is important as a means of feedback. In addition to this, the item that was mostly (36.1\%) and strongly $(26.2 \%)$ agreed by the participants was Item 5 . As it is understood, $62.3 \%$ of the teachers see assessment as an integrated process with teaching practice.

The items that were moderately agreed by the participants were Item $6,12,14,15,22,23,24$. Among these items, item 6,15 , and 24 are related to assessment results, and $37.7 \%$ of the teachers moderately agreed with Item $6,29.5 \%$ of the teachers moderately agreed with Item 15 , and $27.9 \%$ of the teachers moderately agreed, and $26.2 \%$ of the teachers mostly agreed with Item 24 . These percentages of agreement showed that assessment results are perceived as trustworthy, consistent and can be depended on according to most of the teachers.

Item 12 was moderately agreed by $37.7 \%$ of the teachers and mostly agreed by $29.5 \%$ of the teachers. Similarly, $36.1 \%$ of the teachers moderately agreed, and $31.1 \%$ of the teachers mostly agreed with Item $14,34.4 \%$ of the teachers moderately agreed, and $24.6 \%$ of the teachers mostly agreed with Item 22 , and $32.8 \%$ of the teachers moderately agreed with Item 23 . These items indicated that assessment establishes what students have learned, assessment information modifies ongoing teaching of students, assessment helps students improve their learning, and assessment allows different students to get different instruction.

The item that was mostly disagreed $(18.0 \%)$ by the participants was Item 21 . According to the participants, assessment does not measure students' higher order cognitive skills, such as analyzing and evaluating.

Table 2. Items related to school accountability

\begin{tabular}{|c|c|c|c|c|c|c|c|c|c|c|c|c|}
\hline \multirow{2}{*}{ Items } & \multicolumn{6}{|c|}{ Frequencies } & \multicolumn{6}{|c|}{ Percentages $(\%)$} \\
\hline & SD & MD & Sl.Ag. & Mod.Ag. & MA & SA & SD & MD & Sl.Ag. & Mod.Ag. & MA & SA \\
\hline $\begin{array}{l}\text { 1.Assessment } \\
\text { provides } \\
\text { information on } \\
\text { how well } \\
\text { schools are } \\
\text { doing }\end{array}$ & 0 & 5 & 13 & 18 & 19 & 6 & 0 & 8.2 & 21.3 & 29.5 & 31.1 & 9.8 \\
\hline $\begin{array}{l}\text { 10.Assessment } \\
\text { is an accurate } \\
\text { indicator of a } \\
\text { school's } \\
\text { quality }\end{array}$ & 10 & 6 & 14 & 22 & 9 & 0 & 16.4 & 9.8 & 23.0 & 36.1 & 14.8 & 0 \\
\hline $\begin{array}{l}\text { 19.Assessment } \\
\text { is a good way } \\
\text { to evaluate a } \\
\text { school }\end{array}$ & 5 & 11 & 15 & 24 & 6 & 0 & 8.2 & 18.0 & 24.6 & 39.3 & 9.8 & 0 \\
\hline
\end{tabular}

As it is seen in Table 2, Items 1, 10, and 19 are related to School Accountability. It can be seen that $29.5 \%$ of the teachers moderately agreed, and $31.1 \%$ of the teachers mostly agreed with the Item 1 . It 
demonstrated that $60.6 \%$ of the teachers supported the idea that assessment provides information about how well schools do.

$23.0 \%$ of the teachers slightly agreed, and $36.1 \%$ of the teachers moderately agreed but $16.4 \%$ of the teachers strongly disagreed with Item 10. It indicates that on the one hand, 59.1\% of the teachers partially approve the idea that assessment is an accurate indicator of a school's quality, but on the other hand, on the contrary with this conception, $16.4 \%$ of the teachers do not see assessment as an accurate indicator of a school's quality. Item 19 was slightly agreed by $24.6 \%$ of the teachers and moderately agreed by $39.3 \%$ of the teachers. It shows that $63.9 \%$ of the teachers see assessment as a good way to evaluate schools.

Table 3. Items related to student accountability

\begin{tabular}{|c|c|c|c|c|c|c|c|c|c|c|c|c|}
\hline \multirow{2}{*}{ Items } & \multicolumn{6}{|c|}{ Frequencies } & \multicolumn{6}{|c|}{ Percentages (\%) } \\
\hline & SD & MD & Sl.Ag. & Mod.Ag. & MA & SA & SD & MD & Sl.Ag. & Mod.Ag. & MA & SA \\
\hline 2.Assessment & 3 & 7 & 9 & 24 & 13 & 5 & 4.9 & 11.5 & 14.8 & 39.3 & 21.3 & 8.2 \\
\hline \multicolumn{13}{|l|}{ places students } \\
\hline \multicolumn{13}{|l|}{ into categories } \\
\hline 11.Assessment & 2 & 9 & 10 & 23 & 16 & 1 & 3.3 & 14.8 & 16.4 & 37.7 & 26.2 & 1.6 \\
\hline \multicolumn{13}{|l|}{ is assigning a } \\
\hline \multicolumn{13}{|l|}{ grade or level } \\
\hline \multicolumn{13}{|l|}{ to student } \\
\hline \multicolumn{13}{|l|}{ work } \\
\hline 20.Assessment & 1 & 8 & 18 & 22 & 10 & 2 & 1.6 & 13.1 & 29.5 & 36.1 & 16.4 & 3.3 \\
\hline \multicolumn{13}{|l|}{ determines if } \\
\hline \multicolumn{13}{|l|}{ students meet } \\
\hline \multicolumn{13}{|l|}{ qualifications } \\
\hline standards & & & & & & & & & & & & \\
\hline
\end{tabular}

As it is seen in Table 3, Items 2, 11, and 20 are related to Student Accountability. Item 2 was moderately agreed by $39.3 \%$ of the teachers and mostly agreed by $21.3 \%$ of the teachers. Similarly, $37.7 \%$ of the teachers moderately agreed, and $26.2 \%$ of the teachers mostly agreed with the Item 11 . Besides, $29.5 \%$ of the teachers slightly agreed, and $36.1 \%$ of the teachers moderately agreed with the Item 20. 
Table 4. Items related to irrelevance

\begin{tabular}{|c|c|c|c|c|c|c|c|c|c|c|c|c|}
\hline \multirow[t]{2}{*}{ Items } & \multicolumn{6}{|c|}{ Frequencies } & \multicolumn{6}{|c|}{ Percentages (\%) } \\
\hline & SD & MD & Sl.Ag. & Mod.Ag & MA & SA & SD & MD & Sl.Ag. & Mod.Ag. & MA & SA \\
\hline $\begin{array}{l}\text { 7.Assessment } \\
\text { forces teachers } \\
\text { to teach in a way } \\
\text { against their beliefs }\end{array}$ & 4 & 10 & 20 & 15 & 10 & 2 & 6.6 & 16.4 & 32.8 & 24.6 & 16.4 & 3.3 \\
\hline $\begin{array}{l}\text { 8.Teachers } \\
\text { conduct } \\
\text { assessments but } \\
\text { make little use } \\
\text { of the results }\end{array}$ & 4 & 8 & 16 & 17 & 14 & 2 & 6.6 & 13.1 & 26.2 & 27.9 & 23.03 & 3.3 \\
\hline $\begin{array}{l}\text { 9.Assessment } \\
\text { results should be } \\
\text { treated cautiously } \\
\text { because of } \\
\text { measurement error }\end{array}$ & 0 & 2 & 11 & 13 & 17 & 18 & 0 & 3.3 & 18.0 & 21.3 & 27.9 & 29.5 \\
\hline $\begin{array}{l}\text { 16.Assessment } \\
\text { is unfair to students }\end{array}$ & 11 & 25 & 11 & 7 & 4 & 3 & 18.0 & 41.0 & 18.0 & 11.5 & 6.6 & 4.9 \\
\hline $\begin{array}{l}\text { 17.Assessment } \\
\text { results are filed } \\
\& \text { ignored }\end{array}$ & 5 & 14 & 14 & 17 & 9 & 2 & 8.2 & 23.0 & 23.0 & 27.9 & 14.8 & 3.3 \\
\hline $\begin{array}{l}\text { 18. Teachers } \\
\text { should take into } \\
\text { account the error } \\
\text { and imprecision } \\
\text { in all assessment }\end{array}$ & 0 & 3 & 12 & 11 & 21 & 14 & 0 & 4.9 & 19.7 & 18.0 & 34.42 & 23.0 \\
\hline $\begin{array}{l}\text { 25.Assessment } \\
\text { interferes with } \\
\text { teaching }\end{array}$ & 4 & 4 & 14 & 25 & 10 & 4 & 6.6 & 6.6 & 23.0 & 41.0 & 16.4 & 6.6 \\
\hline $\begin{array}{l}\text { 26.Assessment } \\
\text { has little impact } \\
\text { on teaching }\end{array}$ & 17 & 18 & 12 & 11 & 3 & 0 & 27.9 & 29.5 & 19.7 & 18.0 & 4.9 & 0 \\
\hline $\begin{array}{l}\text { 27.Assessment } \\
\text { is an imprecise } \\
\text { process }\end{array}$ & 7 & 14 & 21 & 11 & 5 & 3 & 11.5 & 23.0 & 34.4 & 18.0 & 8.2 & 4.9 \\
\hline
\end{tabular}

As Table 4 presents, items 7, 8, 9, 16, 17, 18, 25, 26, and 27 are related to Irrelevance Conception. Table 4 shows that $32.8 \%$ of the teachers slightly agreed, and $24.6 \%$ of the teachers moderately agreed with Item 7 . Similarly, $26.2 \%$ of the teachers slightly agreed, and $27.9 \%$ of the teachers moderately agreed with the Item 8.

Item 9 was mostly agreed by $27.9 \%$ of the teachers and strongly agreed by $29.5 \%$ of the teachers. Likewise, $34.4 \%$ of the teachers mostly agreed, and $23.0 \%$ of the teachers strongly agreed with Item 18 . As it is understood, $57.4 \%$ of the teachers agree that assessment results should be treated cautiously because of measurement error, and teachers should take into account the error and imprecision in all assessment.

The item that was mostly disagreed $(41.0 \%)$ by the participants was Item 16 . It indicates that the participants disapprove the idea that assessment is unfair to students. Similarly, $29.5 \%$ of the learners 
mostly disagreed, and $27.9 \%$ of them strongly disagreed with Item $26.23 .0 \%$ of the teachers slightly agreed, and $27.9 \%$ of the teachers moderately agreed but $23.0 \%$ of the teachers mostly disagreed with Item 17. It indicates that on the one hand, $50.9 \%$ of the teachers partially approve the idea that assessment results are filed \& ignored, but on the other, on the contrary with this conception, $23.0 \%$ of the teachers think that assessment results are not filed and ignored.

Item 25 was slightly agreed by $23.0 \%$ of the teachers and moderately agreed by $41.0 \%$ of the teachers. This result demonstrates that the teachers believe assessment interferes with teaching. Item 27 indicated that $23.0 \%$ of the teachers mostly disagreed, and $11.5 \%$ of them strongly disagreed while $34.4 \%$ of the teachers slightly agreed, and $18.0 \%$ of the teachers moderately agreed with Item 27 .

\subsubsection{Correlations among the four components of TCoA-IIIA}

As it is seen in Table 5, this section presents the relationship among the four components of TCoA-IIIA called as Improvement, School Accountability, Student Accountability, and Irrelevance. Pearson Correlation analysis was implemented to reveal the relationship between these four components.

Table 5. Correlation results for teachers' perceptions of assessment

\begin{tabular}{|c|c|c|c|c|c|}
\hline & & IMP & SCHACC & STUDACC & IRR \\
\hline \multirow{3}{*}{ IMP } & Pearson Correlation & 1 & $.71^{* *}$ & $.45^{* *}$ & .03 \\
\hline & Sig. (2-tailed) & .00 & .00 & .78 & \\
\hline & $\mathrm{N}$ & 61 & 61 & 61 & 61 \\
\hline \multirow{3}{*}{ SCHACC } & Pearson Correlation & $.71^{* *}$ & 1 & $.46^{* *}$ & .03 \\
\hline & Sig. (2-tailed) & .00 & .00 & .83 & \\
\hline & $\mathrm{N}$ & 61 & 61 & 61 & 61 \\
\hline \multirow{4}{*}{ STUDACC } & Pearson Correlation & $.45^{* *}$ & $.46^{* *}$ & 1 & $.32^{*}$ \\
\hline & Sig. (2-tailed) & .00 & .00 & .01 & \\
\hline & $\mathrm{N}$ & 61 & 61 & 61 & 61 \\
\hline & Pearson Correlation & .03 & .03 & $.32^{*}$ & 1 \\
\hline \multirow[t]{2}{*}{ IRR } & Sig. (2-tailed) & .78 & .80 & .01 & \\
\hline & $\mathrm{N}$ & 61 & 61 & 61 & 61 \\
\hline
\end{tabular}

**. Correlation is significant at the 0.01 level (2-tailed).

*. Correlation is significant at the 0.05 level (2-tailed).

IMP= IMPROVEMENT

SCHACC $=$ SCHOOL ACCOUNTABILITY

STUDACC $=$ STUDENT ACCOUNTABILITY $\quad$ IRR $=$ IRRELEVANCE 
Table 5 presents correlations among four components of the BILSEM English language teachers' perceptions of assessment. In Table 5, it is observed that all correlations among components are in positive direction. The table demonstrates that there is a strong, positive and significant correlation between Improvement and School Accountability in perceptions of assessment, $r=0.71, \mathrm{p}<0.01$. The correlation between Improvement and Student Accountability is moderate, positive and significant, $\mathrm{r}=$ $0.45, \mathrm{p}<0.01$. However, the correlation between Improvement and Irrelevance is so poor, and there is not a significant difference between these components, $r=0.03, \mathrm{p}>0.05$.

There is a moderate, positive and significant correlation between School Accountability and Student Accountability, $\mathrm{r}=0.46, \mathrm{p}<0.01$. However, the correlation between School Accountability and Irrelevance is so poor, and there is not a significant difference between these components, $\mathrm{r}=0.03$, $\mathrm{p}>0.05$. Lastly, the correlation between Student Accountability and Irrelevance is poor, but there is a significant difference between these components, $\mathrm{r}=0.32, \mathrm{p}<0.05$.

\subsubsection{Results of the teachers' perceptions of assessment practices}

As it is seen in Table 6, this section presents the BILSEM English language teachers' perceptions of assessment practices. The teachers were asked to answer the following question: What types of assessment practices do you have in mind and choose when you think about assessment? (Unplanned Observation, Oral Question \& Answer, Planned Observation (e.g., Running Record, Checklist), Student Written Work (e.g., activity sheets, spelling or math facts), Marked Homework, Student Self or Peer Assessment, Conferencing, Portfolio / Scrapbook, Teacher Made Written Test, Standardized Test, Essay Test, and 1-3 Hour Examination)it is seen in Table 6, this section presents the Burdur and Isparta BILSEM English language learners' perceptions of assessment practices. The students were asked to answer the following question: When you think of the word assessment, which kinds or types of assessment activities come to your mind?

Table 6. Teachers' perceptions of assessment practices

\begin{tabular}{lcc}
\hline Assessment Practices & Frequency & Percentage (\%) \\
\hline Unplanned Observation & 33 & 54 \\
Oral Question \& Answer & 46 & 75 \\
Planned Observation & 46 & 75 \\
(e.g., Running Record, Checklist) & 50 & 82 \\
Student Written Work (e.g., & & \\
activity sheets, spelling or math & & \\
facts) & 26 & 73 \\
Marked Homework & 44 & 72 \\
Student Self or Peer Assessment & & \\
\hline
\end{tabular}




$\begin{array}{lcc}\text { Conferencing } & 12 & 20 \\ \text { Portfolio / Scrapbook } & 44 & 72 \\ \text { Teacher Made Written Test } & 32 & 52 \\ \text { Standardised Test } & 32 & 52 \\ \text { Essay Test } & 21 & 34 \\ \text { 1-3 Hour Examination } & 19 & 31\end{array}$

Table 6 demonstrates that Student Written Work (e.g., activity sheets, spelling or math facts) (82\%), Oral Question \& Answer and Planned Observation (e.g., Running Record, Checklist) (75\%), Student Self or Peer Assessment and Portfolio / Scrapbook (72\%), Unplanned Observation (54\%), and Teacher Made Written Test and Standardized Test (52\%) are the types of assessment practices commonly preferred by the teachers to assess their students' language performances in their classes. However, Conferencing $(20 \%)$ is the least preferred assessment practice that is used by the teachers in their classes.

\subsubsection{Results of the teachers' choices of types of assessment and assessment practices}

In the last part of the survey, the researchers asked the BILSEM English language teachers five multiple choice questions aiming to learn their choices of daily assessment types and assessment practices that they generally use in their classes. More specifically, the teachers were asked to answer the following questions: Do you use the alternative assessment methods, such as self- and peerassessment, portfolio assessment, etc. properly and effectively to judge your students' English knowledge or to learn whether they understand the topic or not in your classes at BILSEM?, How are your students' reactions to the alternative assessment methods used to assess them in English classes at BILSEM?, Which assessment type is more effective for your students' gaining four language skills in English? Traditional or alternative assessment or both of them?, Which assessment type(s) is/are more effective for your students' gaining critical thinking skills and creativity?, and Which assessment method(s) do you prefer and implement in your classes? These multiple choice questions were asked in order to make the results elicited through the first and second part of the questionnaire more specific.

As it is clearly seen, related to the first question "Do you use the alternative assessment methods, such as self- and peer-assessment, portfolio assessment, etc. properly and effectively to judge your students' English knowledge or to learn whether they understand the topic or not in your classes at BILSEM?", Table 7 presents the results of whether the teachers use the alternative assessment methods in their classes. 
Table 7. Teachers' choices of alternative assessment methods

\begin{tabular}{lcc}
\hline Answers & Frequency & Percentage (\%) \\
\hline Yes & 33 & 54.1 \\
No & 1 & 1.6 \\
Partly & 25 & 41.0 \\
I do not use any & 2 & 3.3 \\
alternative assessment & & \\
methods in my classes & 0 & 0 \\
I am not sure & & \\
\hline
\end{tabular}

Table 7 demonstrates that most of the teachers use the alternative assessment methods, such as selfand peer-assessment, portfolio assessment, etc. properly and effectively to judge their students' English knowledge or to learn whether they understand the topic or not in their classes at BILSEM (54.1\% yes, $41.0 \%$ partly).

As it is clearly seen, related to the second question "How are your students' reactions to the alternative assessment methods used to assess them in English classes at BILSEM?", Table 8 presents the results of students' reactions to the alternative assessment methods used to assess them in English classes at BILSEM.

Table 8. Students' reactions to the alternative assessment methods

\begin{tabular}{lcc}
\hline Answers & Frequency & Percentage (\%) \\
\hline Positive & 43 & 70.5 \\
Negative & 3 & 4.9 \\
Neutral & 15 & 24.6 \\
\hline
\end{tabular}

Table 8 indicates that reaction of most of the students to the alternative assessment methods used to assess them in English classes at BILSEM is positive (70.5\% positive).

As it is clearly seen, related to the third question "Which assessment type is more effective for your students' gaining four language skills in English? Traditional or alternative assessment or both of them?", Table 9 presents the effect of types of assessment on students' gaining four language skills in English. 
Table 9. Effect of types of assessment on students' gaining four language skills in English

\begin{tabular}{lcc}
\hline \multicolumn{1}{c}{ Answers } & Frequency & Percentage (\%) \\
\hline Traditional assessment & 0 & 0 \\
Alternative assessment & 34 & 55.7 \\
Both traditional and alternative assessment & 23 & 37.7 \\
I am not sure & 4 & 6.6 \\
\hline
\end{tabular}

Table 9 indicates that according to the teachers, alternative assessment (55.7\%) is more effective for the students' gaining four language skills in English. Besides, 37.7\% of the teachers also think that traditional and alternative assessment both are effective for the students' gaining four language skills in English.

As it is clearly seen, related to the fourth question "Which assessment type(s) is/are more effective for your students' gaining critical thinking skills and creativity?", Table 10 presents the effect of types of assessment on students' gaining critical thinking skills and creativity.

Table 10. Effect of types of assessment on students' gaining critical thinking skills and creativity

\begin{tabular}{lcc}
\hline \multicolumn{1}{c}{ Answers } & Frequency & Percentage (\%) \\
\hline Traditional assessment & 0 & 0 \\
Alternative assessment & 41 & 67.2 \\
Both traditional and alternative assessment & 18 & 29.5 \\
I am not sure & 2 & 3.3 \\
\hline
\end{tabular}

Table 10 indicates that according to the teachers, alternative assessment $(67.2 \%)$ is more effective for the students' gaining critical thinking skills and creativity.

As it is clearly seen, related to the fifth question "Which assessment method(s) do you prefer and implement in your classes?", Table 11 presents which assessment method(s) the teachers prefer and implement in their classes at BILSEM. 
Table 11. Assessment method(s) the teachers prefer and implement in their classes at BILSEM

\begin{tabular}{lcc}
\hline \multicolumn{1}{c}{ Answers } & Frequency & Percentage (\%) \\
\hline Always "Alternative Assessment" & 22 & 36.1 \\
(Self- and Peer-Assessment, Portfolios, & & \\
Journals, Interviews, Discussions, & & 0 \\
Observations, etc.) & 0 & \\
Always "Traditional Assessment" & & 55.7 \\
(Multiple-choice, gap-filling, true/false, & 34 & \\
matching, etc.) & & 4.9 \\
Mostly alternative assessment but & 3 & 3.3 \\
sometimes traditional assessment & 2 & \\
Mostly traditional assessment but & & \\
sometimes alternative assessment & & \\
I do not use any assessment method(s) & & \\
in my classes &
\end{tabular}

Table 11 demonstrates that the teachers prefer and implement mostly alternative assessment but sometimes traditional assessment in their classes at BILSEM (55.7\%). Besides, 36.1\% of the teachers always use alternative assessment, such as self- and peer-assessment, portfolios, journals, interviews, discussions, observations, etc. in order to judge their students' English knowledge or to learn whether they understand the topic or not in their classes at BILSEM.

\subsection{Results of the Qualitative Data}

\subsubsection{Interview Results of Teachers' Opinions about Assessment}

The interviews were conducted with 5 teachers working at BILSEM in different cities. The qualitative data collected from the interviews and open-ended questions was subjected to a peer review. The open review technique was used to examine the qualitative data in this study. Two colleagues of the researchers made reviews on the data obtained from the interviews conducted and gave the researchers recommendations as a reference, and both the reviewers and researchers were familiar with each other during the peer review process. Thus, the researchers added new dimensions and qualifications to their ideas and comments related to the data that they collected, and they made clearer comments about the data in this way.

The first question in the interview is "What is the first thing that comes into your mind when you hear "Traditional Assessment" and "Alternative Assessment"?" The results of the review show that according to the participants, traditional assessment is the process of checking the progress of the students in an unannounced and informal way while alternative assessment can be defined as supportive assessment types, such as self- and peer-assessment, project work, portfolios, learner diaries, and standardized tests. To the participants, while traditional is standard, alternative means 
production. T4 said that alternative assessment means trendy teachers but traditional assessment represents old fashioned ones. In addition, when someone says traditional assessment, the participants think of pen and paper, multiple choice tests that measure students' success at knowledge level. Alternative assessment techniques, on the other hand, provide teachers with the opportunity to see students' knowledge in various dimensions of a single area.

The second question in the interview is: "Which assessment method(s) do you prefer and implement in your classes? Why?" The review of the answers given to this question shows that most of the participants (T2, T3, T4) prefer alternative assessment methods because they assess students' performance and increase the motivation of both good and poor learners. Besides, some of the participants (T1, T5) use both summative and formative and alternative assessment types for the purpose of achieving the reliability and validity for evaluating the students' progress and success.

The third question in the interview is: "Which assessment type is more effective for your students' gaining four language skills in English? Traditional or alternative assessment?" The review of the answers given to this question shows that four participants (T1, T2, T3, T5) stated that alternative assessment methods helped them to identify their students' levels from different dimensions, so the answer is "alternative assessment". Teachers have a chance of getting evaluation in a broader perspective in alternative assessment, and they can see the improvements of students in several areas clearly. Furthermore, if teachers assess and evaluate students from different dimensions, it will be a less likelihood for them to be referred or claimed as subjective, so the participants think that alternative assessment is more effective for their students' gaining four language skills in English and prefer alternative assessment in their classes.

The fourth question in the interview is: "Which assessment type is more effective for your students' gaining critical thinking skills and creativity?" All of the participants stated that alternative assessment is more effective because it gives students more opportunities of research and thinking. While students are searching any information, they read all kinds of materials that present different and conflicting claims and knowledge. So they think over them, evaluate and decide. It is clear that traditional assessment methods are not effective in assessing critical thinking; they assess information at knowledge level. If they are multiple choice questions, then there is no space for assessing critical thinking. Students choose among the readily available options. Therefore, it will be an indispensable and unprejudiced way for a teacher to use alternative assessment types for his/her students, as they can reflect their own perceptions and skills in the learning process, and alternative assessment encourages to process learning.

The fifth question in the interview is: "What kind of challenges have you experienced while implementing traditional and alternative assessment methods so far?" The review of the answers given to this question shows that in traditional, students' physical situation such as being ill, sleepy and even tiredness can affect the result, and students may not have the same chance to get reassessment. In alternative, teachers are tired while grading and evaluating because such evaluation generally needs long reading or writing or oral assessment materials. In fact being assessed by a superior knowledge causes some distress, especially if it is a foreign language class, in the learning environment. So it will be valuable for a teacher to assess his/her students in a friendly environment. However, as teachers need to assess their students, they may face some problems in this assessment 
process; for example, when they implement traditional assessment for them, students can feel uneasy and have a lack of motivation.

In alternative assessment methods, teachers usually encounter time constraint problems in the handing over process. Furthermore, students may also have difficulties when providing some substances for the alternative assessment types. T4 said that: Sometimes I realize that my students have not even heard of the word portfolio. And it becomes hard to use alternative assessment ways. Sometimes it is easier for the teachers to apply the known rather than the unknown. Besides, T5 stated that traditional assessment methods she used gave her clues about only the reading skill of her students, maybe grammar or vocabulary as well. Although they are components of language knowledge, they are just one side of it. This is a big problem, it is not reliable. The participant went on to state that when she uses alternative methods that include various skills/knowledge types, etc., then she comes across some criticisms. People say "How come a student who answers all questions right in tests score lower here?" so it requires a lot of patience and explanations to people.

The sixth question in the interview is "What do you do to cope with the challenges you have while you are implementing the assessment tools in your classes?" The participants stated that before deciding on types of assessment, they have to take into consideration the drawbacks of the classrooms. Especially, these drawbacks arise due to some financial inadequacies of the students. Then, what they should pay attention to is what they aim to assess and whether it is the right assessment tool for the purpose. Some of the teachers (T3, T4) stated that they cope with the challenges by interaction with the students because seeing someone practising is better than hearing it. In addition to this, 3 teachers (T1, T4, T5) believe that what they are doing is right in the long term so they do their best about overcoming the difficulties. They always explain the notion behind their actions to the administration, students, colleagues, and even parents when necessary. It is not easy, it takes a lot of time, but it works.

The seventh question in the interview is: "Alternative assessment is the core and main assessment type used in English classes at BILSEM. Do you think that only the alternative assessment is sufficient to assess the students' all language and thinking skills? Or have you thought using any traditional assessment techniques with the alternative ones to assess what your students have learnt in English classes up to now?" The review of the answers given to this question shows that some of the participants (T1, T2) think that in most of the cases, assessment is a beneficial way for observing and keeping the progress of the students; yet, what they should take into consideration is that they have to be careful about its time constraints, students' learning types and interests rather than the type of assessment. As a result, they prefer to use the assessment which is suitable for the student type, time and their purpose.

According to 2 participants (T1, T2), alternative is mainly sufficient but students may need traditional assessment such as placement tests when the teachers need to place them in groups. On the other hand, 2 teachers (T4, T5) have not used the traditional ones up to now. They think that portfolio assessment comes up with all their students' improvement, and they did not need any traditional assessment scores to have idea about their students' success and knowledge in their lessons. Besides, as for BILSEM, they accept students who all achieve well in traditional assessment methods, so something more is needed, and they are alternative assessment methods. 
The final question in the interview is: "What are your opinions and suggestions for 'Assessment' in English classes at BILSEM?" 3 participants (T3, T4, T5) stated that using alternative ways of assessment gives students joy and encouragement, learning atmosphere by doing and learning in process. Students should not be judged by formal projects; instead their self- assessment should be motivated. 3 participants (T2, T4, T5) suggest that keeping a portfolio and how to keep it can be told as a webinar to BILSEM teachers. They also suggest that assessments should be shared with students' formal school English teachers and students' assessment techniques must have the same so that students can have similar portfolios that can give clear information about students' English level when they go to other BILSEM. Furthermore, they believe that any assessment should include all skills. And students with similar scores should be grouped together in their educational process in BILSEM.

\section{Discussion and Conclusion}

In this part, the results related to quantitative and qualitative components will be discussed relating the findings with the previous studies mentioned in the literature review. Each research question will be presented in sub-titles, and the answers will be given to the questions based on the findings of this study.

5.1. What are the BILSEM English Language Teachers' Perceptions of Assessment in terms of: School Accountability, Student Accountability, Improvement, and Irrelevance?

The percentages of the teachers' agreement about School Accountability subgroup showed that most teachers support the idea that assessment provides information about how well schools do. Most of the teachers also see assessment as a good way to evaluate schools while some of the teachers do not see assessment as an accurate indicator of a school's quality. This indicates that most of the participants see assessment as a useful and valid tool to identify schools' role and function in educational area when they handle the results of it. It is clear that most of the participants understand whether schools support the learning of students and enhance it according to the assessment results of students in a school. In her doctorate thesis, Ludwig (2013) indicates that 88 teachers (55\%) expressed a moderate to strong belief that assessments provide information on how well schools are doing, and it is clearly seen that teachers agreed that assessment makes it possible to evaluate schools.

The BILSEM English language teachers' conception of assessment related to Student Accountability subgroup generally indicated that the teachers use assessment in their classes to place students into categories. In other words, they use assessment in their classes to better understand their students' intellectual development levels, learning types, and learning approaches, such as Behaviorist Approach to Learning, Cognitive Approach to Learning, etc. Also, they use assessment in their classes to assign a grade or level to their students' work and to be able to understand whether their students meet qualifications standards or not. This indicates that teachers make assessments to be able to understand whether students in any grade level, such as primary school, middle school, high school or science and arts center understand the theoretical content of the subject well and turn it into the practical uses of that subject. However, in his study, Brown (2008) stresses that assessments of student learning had little contribution to improved outcomes. Information as to what kind of learning is required by the assessments of student accountability and how those are conceived of by the teachers is needed to make better sense of this contribution. 
According to the results related to Improvement subgroup, most of the teachers think that assessment provides feedback to students about their performance, and it is integrated with teaching practice. Most of the teachers also believe that assessment results are consistent, trustworthy and can be depended on but according to them assessment does not measure students' higher order cognitive skills, such as analyzing and evaluating anyway. Likewise, in the investigation on conceptions of teachers teaching English to young learners concerning assessment in English for young learners' classroom in her master's thesis, Ayas (2014), and in her master's thesis on pre-service English language teachers' conceptions of assessment, Yüce (2015) also obtained the same results related to conception of Improvement. This shows that according to most of the participants, assessment does not support deep cognitive learning, but it provides students to see their deficiencies in subjects, and it creates good opportunities for students to complete their deficiencies properly in a very short time in this way. However, this result contradicts with the answers of the interviewed teachers in this study. One of the questions asked them in interview was whether an assessment type is effective for students' gaining critical thinking skills and creativity, and regarding this question, all interviewed teachers stated that alternative assessment is more effective because it gives students more opportunities of research and thinking.

Lastly, according to the results related to Irrelevance subgroup, it is obvious that assessment is a force to make teachers teach in a way that is against their beliefs, and assessment is of little use because teachers make little use of assessment, although they conduct it. This clearly shows that teachers do not take advantage of assessment results properly in their classes. This situation may stem from their lack of knowledge about how to use assessment results as it deserves. Also, teachers think that assessment is fair to students and has an important impact on teaching. Besides, as it is understood from the frequency and percentage analyses, while some teachers think that assessment is an accurate process, most teachers see assessment as an imprecise process. Regarding this result, in his doctorate thesis, Brown (2002) stresses that the conception of irrelevance identified that assessment has nothing to do with teaching and therefore not important, it is something that students will not like, and the results of it are not precise. According to him, there may be a close connection between this irrelevance conception and student-centered teaching, too.

\subsection{What is the Relationship among the Four Components of TCoA-IIIA?}

The correlation results demonstrated that there is a significant correlation between Improvement and School Accountability, between Improvement and Student Accountability, and between School Accountability and Student Accountability in perceptions of assessment. However, the correlation results also showed that there is not a significant difference between Improvement and Irrelevance, and between School Accountability and Irrelevance. On the other hand, the correlation results showed that although the correlation between Student Accountability and Irrelevance is poor, there is a significant difference between these components. It can be said that the BILSEM English language teachers see assessment as a way to determine how much students have learned from teaching and as a measure of helping students improve their learning in order to determine if students meet qualifications standards. At this point, the results of this study are similar to the findings of Yüce (2015) who also found out that pre-service English language teachers in the group in her study conceived of assessment as diagnosing and improving students learning in order to meet standards of student achievement. She also found that pre-service English language teachers conceived of 
assessment as a good and accurate indicator of raising of educational standards. Furthermore, the correlation results between Improvement and School Accountability in this study are consistent with the study conducted by Brown (2011). In this study, there was a strong correlation between Improvement and School Accountability, and according to the results of Brown's study (2011), there was a moderate correlation between them. According to him, this correlation means improving teaching and learning process is directly proportional to assessing students. Besides, the BILSEM English language teachers see assessment as a good way to evaluate a school.

In this study, irrelevance is slightly correlated with Improvement, School Accountability, and Student Accountability. The correlation between Irrelevance and these three other conceptions demonstrated that the English language teachers in this study also slightly see assessment as an unfair way to assess students and as an imprecise process in educational area. Likewise, in the study of Yüce (2015), irrelevance was moderately correlated with Improvement, School Accountability, and Student Accountability. According to her, the correlation between Irrelevance and these three other conceptions showed that pre-service English language teachers also moderately conceived assessment as something that the students do not enjoy and see its results as imprecise, and therefore they ignore the results of it.

\subsection{What Types of Assessment Practices do the BILSEM English Language Teachers Choose?}

The results showed that the BILSEM English language teachers use the types of assessment practices such as Student Written Work (e.g., activity sheets, spelling or math facts), Oral Question \& Answer and Planned Observation (e.g., Running Record, Checklist), Student Self or Peer Assessment and Portfolio / Scrapbook, Unplanned Observation, and Teacher Made Written Test and Standardised Test to assess their students' language performances in their classes. However, Conferencing is the least preferred assessment practice that is used by the teachers in their classes. Also, the interviewed teachers stated that they prefer to use the assessment practices which are suitable for the student type, time and their purpose in their classes. Teachers' perceptions of assessment are important as they influence assessment practices teachers use in the classroom (Brown, 2004), and these practices may develop teacher instruction and improve student learning (Hao \& Johnson, 2013).

It can be said that the teachers used Student Written Work assessment practice mostly to assess their students' language performances and language achievement in their classes. This shows that language performances of the English language learners studying at BILSEM were assessed mostly through their own written works, such as activity sheets, spelling or math facts. In addition, their language performances were also assessed mostly through Oral Question \& Answer and Planned Observation (e.g., Running Record, Checklist), Student Self or Peer Assessment, and Portfolio / Scrapbook assessment practices. These results show that the BILSEM English language teachers' conceptions of assessment do not contradict with their choices of assessment tasks in practice. In other words, their conception of assessment is mostly related to improvement of the students, and in parallel with this result, their choices of assessment tasks in practice are mainly alternative types of assessment, such as student self or peer assessment and portfolio. The review of the answers given to the questions about alternative assessment in interviews also shows that most of the teachers prefer alternative assessment methods in their classes because they assess students' performance and increase the motivation of both good and poor learners in this way. This might be a result of the fact that alternative assessment is integrated into the curriculum of BILSEM, and thus the school curriculum supports such an 
assessment type in particular. In addition to this, this might also be a result of the fact that most of the English language teachers teaching at BILSEM also have positive perceptions about alternative assessment, have the necessary and enough information about the alternative assessment methods, and use them in their classes.

When the results in this study were compared with Vardar's study (2010), the situation was different in her study. According to the statistics, in her study, the assessment tools commonly used by the sixth, seventh and eighth grade teachers were Multiple Choice, Performance-Task, Fill-in-the Blanks, True-False, Project, Short Answer, Group-Work, Matching, Portfolio, and Drama. She stressed that most of the participant teachers in her study selected the traditional assessment tools. Besides, it was the same situation in Ayas's study (2014), too. In her study, conceptions of assessment of the teachers teaching English to young learners contradicted with their choices of assessment tasks in practice. Their conception of assessment was mostly related to improvement of the students, but their choices of assessment tasks in practice were mainly traditional types of assessment, such as teacher made written test and standardized tests.

According to Ayas (2014), the contribution of alternative assessment practices to education is clear, so it could be much better to argue that the teachers need to use these assessment practices to make learning more effective in their classroom courses. Moreover, according to Fisher and Frey (2014), "only formative assessment practices can deliver timely data about what students understand. Without formative assessment data, teaching is aimed at the middle. We'll never know which students were ready for a stretch, and which needed reteaching" (p. vii).

It can be clearly stated that Conferencing was the least preferred assessment practice that is used by the teachers in their classes to assess their students' language performances although the teachers can give direct feedback to the students about their works orally or in a written way easily and quickly by holding a series of meetings or conferences. Similar to the results in this study, Yüce (2015) also found that pre-service English language teachers' language performances were also assessed through Student Written Work assessment technique, such as activity sheets, and Conferencing technique was the least preferred assessment tool by their language teachers, too. She also stressed that pre-service English language teachers think of using Student Written Work and Conferencing assessment tools more than their teachers did.

\section{References}

Airasian, P. W., \& Russell, M. K. (2012). Classroom assessment: Concepts and applications (7th ed.). New York, NY: McGraw-Hill.
Assessment.
(n.d.).
Retrieved
October
11 ,
2016,
from www.education.vic.gov.au/Documents/.../assessmentpres.

Ayas, N. (2014). An investigation of teachers' conception and practices concerning assessment in English for young learners classroom. Unpublished master's thesis, University of Çağ, Mersin, Turkey. 
Brown, G. T. L. (2003, November). Teachers' instructional conceptions: Assessment's relationship to learning, teaching, curriculum, and teacher efficacy. Paper presented to the Joint Conference of the Australian and New Zealand Associations for Research in Education (AARE/NZARE), Auckland, NZ.

Brown, G. T. L. (2004). Teachers' conceptions of assessment: implications for policy and professional development. Assessment in Education, 11(3), 301-318.

Brown, G. T. L. (2006). Teachers' conceptions of assessment inventory--Abridged (TCoA-IIIA-Version 3-Abridged). Unpublished test. Auckland, NZ: University of Auckland.

Brown, G. T. L. (2007). Teachers' conceptions of assessment: comparing measurement models for primary \& secondary teachers in New Zealand. Paper presented to the New Zealand Association for Research in Education (NZARE) annual conference, Christchurch, NZ.

Brown, G. T. L. (2008). Conceptions of assessment: Understanding what assessment means to teachers and students. New York: Nova Science Publishers.

Brown, G. T. L. (2011). Self-regulation of assessment beliefs and attitudes: A review of the students' conceptions of assessment inventory. Educational Psychology, 31(6), 731-748.

Brown, G. T. L. \& Michaelides, M. P. (2011). Ecological rationality in teachers' conceptions of assessment across samples from Cyprus and New Zealand. European Journal of Psychology of Education, 26(3), 319-337.

Brown, H. D. (2004). Language assessment: Principles and classroom practices. New York: Pearson Education, Inc. Publications.

Büyükkarcı, K. (2010). The effect of formative assessment on learners' test anxiety and assessment preferences in EFL context. Unpublished doctoral thesis, University of Çukurova, Adana, Turkey.

Büyüktokatlı, N., \& Bayraktar, Ş. (2014). Fen eğitiminde alternatif ölçme değerlendirme uygulamaları. Pegem Eğitim ve Öğretim Dergisi, 4(1), 103-126.

Chamot, A. U., Barnhardt, S., El-Dinary, P. B., \& Robbins, J. (1999). The learning strategies handbook. White Plains, NY: Addison Wesley Longman.

Coombe, C., Folse, K., \& Hubley, N. (2007). A practical guide to assessing English language learners. The University of Michigan: The University of Michigan Press.

Davis, D. S., \& Neitzel, C. (2011). A self-regulated learning perspective on middle grades classroom assessment. The Journal of Educational Research, 104(3), 202-215.

Fisher, D., \& Frey, N. (2014). Checking for understanding: Formative assessment techniques for your classroom (2nd ed.). Alexandria, VA: ASCD Publication.

Glossary of Important Assessment and Measurement. (n.d.). Retrieved October 10, 2016, from http://www.ncme.org/ncme/NCME/Resource_Center/Glossary/NCME/Resource_Center/Glossa ry1.aspx?hkey=4bb87415-44dc-4088-9ed9-e8515326a061\#anchorA

Gülbahar, Y., \& Büyüköztürk, Ş. (2008). Değerlendirme tercihleri ölçeğinin Türkçeye uyarlanması. Hacettepe Üniversitesi Eğitim Fakültesi Dergisi, 35 (35). 
Hao, S., \& Johnson, R. L. (2013). Teachers' classroom assessment practices and fourth-graders' reading literacy achievements: An international study. Teaching and Teacher Education, 29, 53-63.

Huba, M. E., \& Freed, J. E. (2000). Learner-centered assessment on college campuses: Shifting the focus from teaching to learning. The USA: Pearson Publications.

Kahn, E.A. (2000). A case study of assessment in a grade 10 English course. The Journal of Educational Research, 93(5), 276-286.

Lambert, D., \& Lines, D. (2000). Understanding assessment: Purposes, perceptions, practice, London: RoutledgeFalmer Publications.

Lambert, M. (2012). A beginner's guide to doing your education research project. Chennai, India: Sage.

Sadler, D. R. (1989). Formative assessment and the design of instructional systems. Instructional Science 18: 119-144.

Şahin, Ç.,\& Karaman, P. (2013). Sınıf öğretmeni adaylarının ölçme ve değerlendirmeye ilişkin inançları. Hacettepe Üniversitesi Eğitim Fakültesi Dergisi, 28(28-2).

Vardar, E. (2010). Sixth, seventh and eighth grade teachers' conception of assessment. Unpublished master's thesis, Middle East Technical University, Ankara, Turkey.

Wiggins, G. (1998). Educative assessment: Designing assessments to inform and improve student performance. San Francisco, Calif.: Jossey-Bass.

Yayla, G. (2011, April). Fen ve teknoloji öğretmenlerinin tecrübeleriyle alternatif ölçme ve değerlendirme yaklaşımlarına yönelik öz yeterlilikleri arasındaki ilişki. Paper presented in the 2nd International Conference on New Trends in Education and Their Implications, Antalya, Turkey.

Yüce, Z. (2015). Pre-service English language teachers' conceptions of assessment and assessment practices. Unpublished master's thesis, University of Çă̆, Mersin, Turkey. 